УДК 061.26316.3

DOI: $10.32837 / 2519-8858 / 10 / 130$

Андрій Васильович Матвійчук

Кандидат політичних наук, старший науковий співробітник Фондів Президентів України, Національна бібліотека України імені В.І. Вернадського, м. Київ, Україна

\title{
ДІЯЛЬНІСТЬ МІЖНАРОДНИХ НЕУРЯДОВИХ ОРГАНІЗАЦІЙ У ЗАКОНОДАВЧО-ПРАВОВОМУ ПОЛІ УКРАЇНИ
}

\begin{abstract}
Анотація. Сформульовано визначення поняття «міжнародна неурядова організація» (МНУО) як організоване об'єднання представників громадськості різних країн, створене відповідно до національного законодавства для досягнення цілей i завдань розвитку громадянського суспільства й міжнародних відносин, що діє відповідно до загальновизнаних принципів Уставу ООН і норм міжнародного права на території двох і більше держав і володіє консультативним статусом. 3'ясовано, що видовими ознаками, які містять у собі: цілі й завдання, характер діяльності, форму організації, наявність консультативного статусу тощо визначається відмінність міжнародної НУО від інших суб'єктів міжнародних відносин. Такі родові ознаки (як от: факт об'єднання людей, наявність постійних органів управління, Статуту тощо) є загальними для всього класу (роду) організацій. Обгрунтовано, що МНУО як учасник міжнародних відносин, $\epsilon$ суб'єктом міжнародного права, однак їх правосуб'єктність має функціональний характер, тобто обмежений іiі консультативним статусом. Продемонстровано, що МНУО є неофіційною сполучною ланкою між національними урядами й міжнародним співтовариством, беруть активну участь у розробці міжнародних стандартів, методів, моделей і співвідносять їхню національну значимість з міжнародно-правовою. Зазначається, що у національному законодавстві України спостерігається тенденція оптимальної розробки питань, що стосуються правового статусу МНУО 3 огляду на міжнародні принципи й стандарти. Водночас, не можна йти шляхом повного їхнього копіювання, оскільки держава, грунтуючись на своєму суспільно-історичному досвіді, досвіді функціонування правової системи, на існуючих суспільних відносинах і своїх національних інтересах, сама має право визначати правовий статус МНУО. Пропонується у змінах до закону «Про неурядові організації» відобразити основну ідею, яка полягає в тому, що неурядові організації $\epsilon$ ядром громадянського суспільства, найважливішим фактором розвитку демократичної держави й міжнародних відносин, засобом реалізації громадянами своїх прав $\mathrm{i}$ свобод..
\end{abstract}

Ключевые слова: міжнародна неурядова організація, національне законодавство, право, суб'єкт міжнародних відносин.

Постановка проблеми. Міжнародні неурядові організації (МНУО) - це громадські об'єднання індивідів, які беруть участь у політичні діяльності, у тому числі і поза межами держави свого перебування. Незважаючи на законодавче закріплення статусу України як демократичної і правової держави (ст. 1 Конституції України), на жаль, розвиток демократії в Україні гальмується ускладненням соціально-економічних та політичних проблем перехідного періоду. У зазначених умовах особливого значення набувають питання про співвідношення старого світогляду та нових реалій, напряму думок вільної людини та напряму іiі дій у певному соціумі. Саме вирішення цієї гострої суперечності є вирішальною передумовою подолання природного неприйняття людиною швидких змін та реального переходу від тоталітарного до демократичного суспільства - суспільства вільних громадян України.

Як особлива форма суспільної свідомості людини світогляд формує спрямованість, тип активної особистості, іiї натуру як діяча. На підставі світогляду людина формує головні орієнтири життєдіяльності - цілі, ідеали, критерії оцінки й особистого вибору, життєві проекти, приймає ті чи інші життєво важливі рішення, їхня реалізація і становить сенс життя людини. Людина переважно орієнтується на суспільство як основну цінність. Формуванню нового світогляду сприяють саме МНУО. Для України діяльність таких організацій $\epsilon$ необхідною, насамперед через те, що українські неурядові організації не мають значної довіри у більшості громадян. Міжнародні організації можуть забезпечити надійний контроль 
за діяльністю влади, у першу чергу завдяки своій незаангажованості. У зв'язку із цим, дослідження діяльності міжнародних неурядових організацій через призму правового аналізу $\epsilon$ актуальним.

Основною проблемою 3 якою стикаються міжнародні неурядові організації, $\epsilon$ недосконалість правової бази. Так, нині діюче українське законодавство у цій сфері передбачає доволі складну процедуру реєстрації [1]. Крім Міністерства юстиції України, необхідна реєстрація також і в інших державних органах (податкова інспекція тощо), що забирає декілька місяців. Подібна бюрократія ускладнює створення організацій та знижує громадську активність тому, що людина вже на підсвідомому рівні не бажає ускладнювати собі життя.

Важливим $\epsilon$ також соціальний аспект. В Україні, ймовірно, понад 95\% загальнонаціонального багатства сконцентровано в руках лише кількох сотень найбагатших людей. Участь десятків партій у виборах ілюструє фінансову опору партій на "кормову базу" олігархів, а не більшості громадян. Звісно, ці політичні партії відстоюють інтереси своїх "патронів". Такий стан речей призводить до неможливості створення саме "українських" міжнародних неурядових організацій [2]. Натомість у нас здійснюють активну діяльність міжнародні організації, які базуються в іноземних країнах, нерідко і за проектами іноземних спецслужб. Такі організації не завжди працюють із урахуванням українських інтересів, а інколи навіть проти них [3]. Отже, українське законодавство потребує значного удосконалення у цій сфері із урахуванням національних інтересів нашої держави.

Мета статті - розкрити правовий статус МНУО, їх національний й міжнародний характер, проблеми правового регулювання в окремих країнах і в Україні, зокрема.

Виокремити МНУО в царині великої кількості різноманітних міжнародних організацій дає змогу аналіз міжнародних конвенцій, актів зарубіжного національного та міжрегіонального законодавства, загальнотеоретичних та спеціальних наукових праць таких авторів як: Н. Білик, О. Бурлак, А. Галай, С. Малашко, О. Голіченко, О. Кокошинський, О. Корнієвський, І. Погорська, М. Рижков та ін.), а також інших фахівців з міжнародного права: Є. Захаров, В. Коструба, А. Матвієнко, В. Пахолок та ін.

Важливо виділити як джерело інформації у процесі вивчення цього питання Міжнародний центр некомерційного права (International Center for Not-for-Profit Law, далі ICNL). Ця міжнародна організація надає правову, інформаційну, експертну та консультативну підтримку в більш ніж 60 державах світу під час розробки та розвитку законодавства, що регулює створення та діяльність некомерційних організацій. ICNL здійснює свою діяльність за фінансової підтримки Американського агентства з міжнародного розвитку (USAID) [4, с.353-357].

Віддаючи належне науковому пошуку, сьогодні все ж можна констатувати факт відсутності єдиної думки стосовно компетенції зазначених організацій, визначення їхнього правового статусу [5]; недостатньо вивчені форми та шляхи впливу діяльності МНУО на міжнародні відносини, не повністю визначений потенціал їхнього впливу на вирішення міжнародних проблем, оминається питання щодо перспектив и їхнього розвитку [6]. Важливою ця тема $є$ і для України, бо роль та вплив МНУО на розвиток держави значно збільшуються [7].

Виклад основного матеріалу. Зараз активно вивчається сутність МНУО, їхній правовий статус, закономірність появи, сфера діяльності та зростаюча роль в наданні допомоги державам та міжнародним міжурядовим організаціям (далі - ММУО) у вирішенні питань, пов'язаних з безпекою, енергетикою та нафтогазовим сектором, захистом прав людини, охороною навколишнього середовища тощо.

Водночас широко дебатується і питання міжнародно-правової відповідальності МНУО, їхній вплив на публічну владу багатьох держав. Зауважимо, що у 2006 році глави одинадцяти провідних міжнародних організацій, що виступають на захист прав людини, довкілля i соціального розвитку, підписали Хартію загальної відповідальності міжнародних неурядових організацій [8], чим підкреслили прозорість своєї діяльності. В основі цієї акції лежить ряд

(C) А. В. Матвійчук, 2019 
особистих, національних і галузевих ініціатив, розпочатих МНУО з метою встановлення єдиних стандартів підзвітності і розробки загальних етичних норм. Незважаючи на те, що діяльність цих організацій регулюється правовими нормами тих країн, де вони здійснюють свою діяльність, Хартія відповідальності міжнародних неурядових організацій є першою такого роду ініціативою, яка покликана розробити міжнародні міжгалузеві стандарти діяльності в неурядовому секторі.

Та на жаль, у сучасному міжнародному праві немає норм, які б офіційно визнавали правосуб'єктність МНУО [9]. 3 іншого боку, відсутні норми, що заперечували б можливість МНУО бути суб'єктом міжнародного права. Відсутня єдина відпрацьована термінологія, яка б дала змогу виділити зі значної кількості категорій міжнародних організацій міжнародну неурядову.

Історія виникнення перших міжнародних організацій бере свій початок 3 часів Стародавньої Греції, де у 6 ст. до н. е. були створені первинні постійні міжнародні об'єднання - Лакедемська та Делоська симахії, що були своєрідними прообразами майбутніх міжнародних організацій, та вже тоді впливали на відносини між грецькими державами: подібно іншим соціальним факторам, вони зближували народи та сприяли їхній меншій замкненості.. Розвиток міжнародних економічних зв'язків, державних відносин, самого міжнародного права як механізму регулювання цих відносин спричинив еволюцію нових форм міжнародного багатостороннього спілкування, якими стали адміністративні унії. В основному вони складалися в галузі митних відносин та мали тимчасовий характер [2].

Наступним етапом розвитку міжнародних організацій було створення міжнародних економічних та митних об'єднань. Першим таким союзом був Ганзейський торговий союз, який вивів Північну Німеччину із стану середньовічного варварства. На початку XIX ст. був створений Німецький митний союз. Всі держави, що увійшли до цього союзу, повинні були підпорядковуватися однаковим законам стосовно ввезення, вивезення та транзиту товарів. Всі митні тарифи визнавалися загальними і розподілялися між членами Союзу за кількістю населення. Спеціалісти в галузі права міжнародних організацій вважають, що першою міжнародною міжурядовою організацією в ії класичному розуміння була Центральна комісія з судноплавства Рейном, створена у 1831 році [10, с.287].

У середині XIX ст. потреба реорганізації міжнародних відносин та спілкування була основою створення постійних міжнародних міжурядових організацій, що мали постійні органи (Всесвітній телеграфний союз, Всесвітній поштовий союз). Ці організації, зазвичай, мали обмежену чи спеціальну компетенцію та досить слабку організаційну структуру. Створення подібних організацій відіграло важливу роль, значно збагативши досвід міжнародного спілкування, який вже через кілька десятиліть дав змогу створити нову форму організації міжнародних відносин - Лігу Націй. Це була перша політична універсальна міжнародна організація.

У середині XIX та початку XX століття право міжнародних організацій вважалося частиною міжнародного адміністративного права. Як писав фахівець з міжнародного права П. Казанський, "міжнародну адміністрацію чекає велике майбутнє, розвиток міжнародних відносин буде складатися більшою мірою з розвитку міжнародного права. Світове життя ставить завдання, які не під силу окремим народам. Вони будуть змушені об'єднуватися в крупні союзи для того, щоб спільними зусиллями досягти загальних цілей" $[11$, с.36].

Згодом, у 40-х роках минулого століття через свою недосконалість, недієздатність Ліги Націй та ускладненість в діяльності через об'єктивні причини було прийнято рішення про створення нової міжнародної організації, що підтримувала мир та міжнародне спілкування $\mathrm{OOH}[12$, с.436-437]. Це безперечне досягнення у сфері розвитку міжнародного права, міжнародних відносин та самих міжнародних організацій.

Початком створення міжнародних неурядових організацій справедливо вважають багатосторонні зустрічі - конгреси, конференції тощо. До початку XX ст. почала збільшуватися кількість конгресів, конференцій та зустрічей, що призвело до формування нового інституту міжнародного спілкування - МНУО. Перші такі організації мали головним

(C) А. В. Матвійчук, 2019 
чином просвітницький і науковий, релігійний, пацифістський та господарчий характер [268].

У середині минулого століття кількість МНУО різко збільшилася. Якщо до того часу існувала незначна їхня кількість і вони не впливати на діяльність держав, то із закінченням Другої Світової війни ситуація різко змінилася. Суспільство відчуло нагальну потребу в організації громадськості різних держав для спільного успіху. Значний вплив мав та має процес глобалізації, що на сьогодні набув великого розмаху. Серед причин, які впливають на збільшення кількості МНУО слід виділити наступні:

- недостатні можливості окремих держав та міжнародних міжурядових організацій для вирішення нових міжнародних проблем;

- посилення демократичних процесів у сфері внутрішніх та міжнародних відносин;

- зростаюче бажання індивідів збільшити контроль за процесом прийняття рішень у питаннях, які стосуються їхніх життєвих інтересів (екологія, права людини, економічний та політичний розвиток);

- трансформація у сфері національних інтересів держав: рух від державних інтересів ("суверенітету") до загальнолюдських цінностей - таких, як права людини та захист навколишнього середовища;

- розширення можливостей транскордонних зв'язків та діяльності суспільства різних держав, можливостей технологічного прогресу [3, с.344-348].

Базовим джерелом, яке згадує неурядові організації, є Статут ООН, а саме його ст. 71 де говориться, що Економічна та Соціальна Рада уповноважується проводити необхідні заходи для консультацій з неурядовими організаціями, що зацікавлені у питаннях, які входять до іï компетенції. Такі заходи можуть бути встановлені 3 міжнародними організаціями, а у випадку необхідності - 3 національними організаціями після консультацій із зацікавленим членом Організації. Важливо зазначити, що Статут ООН не дає визначення неурядових організацій, а лише вказує на те, що це поняття включає в себе міжнародні та національні організації [12, с.345-346].

Економічна та соціальна Рада ООН (далі - ЕКОСОР) уповноважена встановлювати консультативні відносини 3 певними організаціями, що мають назву "неурядові". Встановлені дві категорії консультативного статусу: категорія I (загальний консультативний статус) та категорія II (спеціальний консультативний статус). Окрім того, складається перелік МНУО, що підтримують відносини з ЕКОСОР, але які не мають консультативного статусу (так званий "Перелік"). Консультативний статус категорії I надається тим МНУО, які тісно пов’язані з більшою частиною видів діяльності ЕКОСОР, можуть вносити постійний та суттєвий вклад в діяльність ООН та членський склад яких представляє головні верстви населення в більшості держав світу. Консультативний статус категорії II надається організаціям, що мають спеціальну компетенцію лише в окремих галузях діяльності EKOCOP.

МНУО, яким надано консультативного статусу, мають певні права та обов'язки. Вони можуть вносити пропозиції щодо порядку денного ЕКОСОР, а їхні представники - бути присутніми на його засіданнях, надавати письмові заяви та виступати в Раді ЕКОСОР 3 усними заявами. Обов'язком МНУО, що мають консультативний статус, є надання Комітету 3 організації консультацій 3 неурядовими організаціями (допоміжний орган ЕКОСОР) короткої доповіді щодо своєї діяльності, в якій повинна бути інформація про заходи, що проводяться цією організацією на підтримку діяльності ООН [12, с.345-346].

Починаючи з 1946 року, ЕКОСОР приймає кілька резолюцій, що стосуються консультативних відносин з МНУО. Так, у резолюції від 27 лютого 1950 року вказується, що "будь-яка міжнародна організація, яка не створена на основі міжурядового договору, вважається неурядовою". Торкаючись цього юридичного акту ЕКОСОР, Г. Морозов відзначає, що на практиці взаємодії згаданих структур під це визначення підпадають організації, до складу яких входять члени урядів, урядові органи та урядові службовці [15, c.296].

Із найбільш пізніх можна виділити Резолюцію 1996/31 від 1996 року. Пункт 12

(C) А. В. Матвійчук, 2019 
Резолюції дає пояснення, що під "НУО" для цілей ЕКОСОР розуміється організація, яка не заснована будь-яким державним органом чи на основі міжурядової угоди і відповідає наступним умовам:

- вона має "представницьку структуру";

- має "відповідний механізм звітності перед своїми членами";

- iii члени "здійснюють ефективний контроль за іï політикою та діяльністю шляхом використання права голосу та через інші відповідні демократичні та транспарентні процеси прийняття рішень" [16, с.68-79].

3 перерахованих умов випливає, що організація, котра претендує на консультативний статус, повинна містити поняття "членство", тобто бути асоціацією, об'єднанням, союзом тощо. Поняття "фонду", у випадку розгляду континентальним правом, означає організаційноправову форму юридичної особи, що виключає можливість членства. Виходить, що для цілей ЕКОСОР фонд не може розглядатися як НУО.

Однак серед акредитованих ЕКОСОР організацій є значна кількість фондів. Можливо, цей факт можна пояснити зміною реалій, а саме - інтернаціоналізацією діяльності фондів, яку ЕКОСОР ігнорувати на практиці не могла. Однак, це суперечить Резолюції 1996/31, в якій не визначені ані успадковані від ст. 71 Статуту ООН поняття "неурядова організація", "міжнародна організація" і "національна організація", ані поняття "субрегіонального" та "регіонального" рівня, що з'явилися лише в згаданій Резолюції. Говориться лише наступне (пункт 4 Резолюції 1996/31): "За винятком випадків, коли прямо передбачено інше, термін "організація" означає неурядові організації національного, субрегіонального та міжнародного рівня" [12, с.345].

Чи мався на увазі під "рівнем" інтернаціональний характер членства в організації або іiі органах управління, міжнародна присутність шляхом представництв, територіальне охоплення фактичної діяльності? Відповідь на це питання Резолюція 1996/31 не надає. Але, відповідно до практики Комітету ЕКОСОР з НУО, організація $\epsilon$ міжнародною, якщо у неї $\epsilon$ відділення як мінімум в трьох державах [9, с.46-49].

Наступну двозначність можна побачити в Резолюції 1996/31 в тому, що при встановленні відносин "міжнародних" НУО консультації з певним урядом не потрібні, а 3 "національною" організацією такі відносини можуть бути встановлені лише "після консультації з відповідною державою-членом". В світі не існує системи наднаціональної установи НУО. Будь-яка "міжнародна" НУО є організація, заснована за правом конкретної держави, іншими словами - національна організація [12, с.345]. То, у яких же випадках необхідна консультація 3 національним урядом, а в яких - не потрібна? ЕКОСОР офіційної відповіді не надає.

Далі, хоча різні коментарі та пояснення в публікаціях ООН та ЕКОСОР вказують на те, що організація, яка претендує на консультативний статус, повинна мати некомерційний характер, з самої ст. 71 Статуту ООН цього не слідує. Можливо, це випадково, а можливо пояснюється тим, що ЕКОСОР намагається залишити відкритими двері для організацій будьякого забарвлення, в співробітництві з якими є зацікавленість. Можливо, враховується і той факт, що в багатьох державах, особливо тих, що розвиваються, закон просто не виділяє категорій некомерційної організації. Разом з тим необхідно визнати, що який би простір для інтерпретації не надавали прогалини та суперечності в Резолюції 1996/31, транснаціональних корпорацій у списках акредитованих організацій ми не знайдемо.

Слідом за цим згадана Резолюція звертає значну увагу на будь-яку підтримку, безпосередню чи опосередковану, фінансову чи іншу, яку НУО отримують від уряду, вимагаючи досить детальної звітності про це. Таким чином, саме залежність від уряду розглядається як вирішальний фактор при вирішенні питання про можливість співпраці. Уряди і без того мають достатні важелі впливу в системі ООН. Можливість використання ними ще й НУО як "агентів впливу" не повинна допускатися. Однак, ООН також передбачає можливість надання НУО асоційованого статусу - при Департаменті суспільної інформації секретаріату ООН. Цікаво відзначити, як тракиувалось поняття НУО в публікаціях цього 
департаменту: "Неурядовою організацією $є$ будь-який добровільний союз громадян, що організований на місцевому, державному чи міжнародному рівнях" [17 ].

Таке визначення, хоч і неофіційне, не співпадає з позицією ЕКОСОР. Окрім того воно $є$ досить недосконалим та загальним. Це означає відсутність універсального поняття "НУО" навіть всередині самої системи ООН.

На основі прецеденту і ООН, і ЕКОСОР значна кількість міжнародних міжурядових організацій затвердили консультативний статус для НУО, запровадили системи їхньої акредитації, причому саме трактування того, які організації вважати НУО, відрізняється одне від одного. Серед них i Рада Свропи, яка пішла далі, ніж просто затвердження консультативного статусу.

24 квітня 1986 року Рада Європи розробила Європейську конвенцію про визнання правосуб'єктності міжнародних неурядових організацій [18] (далі - Конвенція РЄ), приєднуючись до якої держави, по суті, погоджуються визнавати за НУО, що засновані відповідно до законодавства інших держав-учасниць Конвенції РЄ, національний режим на основі мінімальних формальностей.

Ст. 1 Конвенції РС зазначає: "Ця Конвенція застосовується до асоціацій, фондів та інших приватних інститутів (далі - НУО), які відповідають наступним вимогам:

a) мають некомерційну суспільно корисну мету міжнародного значення;

b) засновані документом, що регулюється внутрішнім законодавством Сторони;

c) виконують свою діяльність як мінімум на території двох держав;

d) мають зареєстрований офіс на території такої Сторони чи будь-якої іншої Сторони" [18].

Видається, що таке формулювання було прийняте для того, щоб охопити якомога більшу кількість організацій. Будь-який приватний (в значенні "недержавний") інститут вважатиметься НУО, якщо відповідатиме усім чотирьом вимогам. Потрібно зазначити, що Конвенція РС оперує поняттям не "міжнародна неурядова організація", а просто "НУО" [18 ], окрім назви та преамбули.

На практиці, для держави-учасниці Конвенції передбачений нею механізм означає, що правосуб'єктність будь-якої іноземної НУО, що походить 3 іншої держави-учасниці та переслідує некомерційні суспільно корисні цілі міжнародного значення, повинна визнаватися в об'ємі, що надається в державі походження, 3 обмеженнями, що застосовуються до аналогічних національних організацій в державі визнання. Як приклад національно-обумовлених обмежень, можна навести Францію [19], де лише суспільно корисні фонди, створені за правом цієї держави у відповідності з особливою процедурою, можуть отримувати пожертвування у вигляді нерухомості. Ці обмеження мають обов'язково бути встановлені законом. Незастосування Конвенції РС стороною, що приймає на своїй території певну організацію, до будь-якої НУО допускається лише у тому випадку, якщо цілі останньої не відповідають національній та міжнародній безпеці, стабільності та правопорядку. Для визнання правосуб'єктності достатньо надати документи, що підтверджують заснування в державі походження, тобто статут чи документ, що встановлює офіційне підтвердження факту отримання прав юридичної особи (там, де не передбачена реєстрація як така) [18].

Висновки. Правила використання поняття МНУО в міжнародній практиці не уніфіковані, відрізняються одні від одних у міжнародних інститутах, досить часто використовуються у різних значеннях у термінології окремо взятого інституту. Однак, зазначений факт не зменшує важливої ролі, яку відіграють МНУО на міжнародній арені, а лише демонструють відсутність чіткої та однозначної відповіді, які організації необхідно розглядати як "НУО", і особливо, як "МНУО", в понятійному апараті системи ООН. Механізм ідентифікації організації як "НУО" в системі ООН не може слугувати моделлю для національного законодавства. Умовно кажучи, поняття МНУО "не належить" жодній державі. Воно належить усьому світові, його історії та сучасності. Вбачається, що потреба його введення в будь-яке національне законодавство держави повинна враховувати ці

(C) А. В. Матвійчук, 2019 
традиції. Міжнародні НУО у своїй діяльності виражають інтереси міжнародної громадськості, їхньої вимоги й зауваження знаходять висвітлення в міжнародно-правових актах, ураховуються при розробці важливих міжнародних угод, що слід враховувати i Україні.

\section{СПИСОК ВИКОРИСТАНИХ ДЖЕРЕЛ}

1. Єдиний реєстр громадських формувань // http://www.minjust.gov.ua/0/unitarylist/.

2. Кохан Д. Міжнародні неурядові організації, передумови їх виникнення / Д. Кохан // Пам'ять століть. Планета: історичний науковий та літературний журнал / Мін. освіти і науки Укр.; Нац. пед. ун. ім. Михайла Драгоманова та інш. - К., 2010. - № 3 (85). - С. 214-223.

3. Барановський Ф.В. Роль громадських організацій та наукового сектору у виборі моделі національної безпеки України / Ф.В. Барановський // Економічний часопис - 21: науковий журнал / Ін-т трансформації суспільства. - Київ, 2011. - № 1/2. - С. 3-5.

4. Кукіна 3.О. Міжнародний інституційний механізм регулювання діяльності засобів масової інформації / 3.О. Кукіна // Часопис Київського університету права: український науково-теоретичний часопис / Київський ун-т права НАН України, Ін-т держави і права ім. В.М. Корецького НАН України. - К., 2012. - № 2. - С. 354-357.

5. Подшибякин С.А. Правовой статус международных неправительственных организаций / С.А. Подшибякин. - М.: Юрлитинформ, 2006. - 128 с.

6. Неурядові організації Європейського Союзу: порівняльний аналіз громадських організацій України. - К.: ВПЦ "Київський університет", 2002. - 48 с.

7. Бурлак О.В. Специфіка співробітництва міжнародних неурядових організацій 3 національними установами із захисту і заохочення прав людини / О.В. Бурлак // Держава i право: збірник наукових праць. Юридичні і політичні науки / Інститут держави і права ім.Корецького В.М. НАН України. - К., 2010. - Вип. 47. - С. 583-589.

8. Хартія відповідальності міжнародних неурядових організацій. $<$ http://viche.org.ua/to-print?mid=4053

9. Ткаченко А. Особливості правової природи міжнародних неурядових організацій у сучасному міжнародному праві / А. Ткаченко // Підприємництво, господарство і право: науково-практичний, господарсько-правовий журнал / Ін-т приватного права і підпр-ва АПрН України та ін. - К., 2011. - № 7 (187). - С. 46-49.

10. Бекяшев К.А. Международное публичное право / К.А. Бекашев. - М.: ТК Велби, Проспект, 2005. - 784 с.

11. Казанский П.Е. Учение о международной администрации / П.Е. Казанский. Одесса, 1901. - 43 с.

12. Політологічний енциклопедичний словник / Упорядник В.П. Горбатенко; За ред. Ю.С. Шемчученка, В.Д. Бабкіна, В.П. Горбатенька. - 2-ге вид., доп. і перероб. - К.: Генеза, 2004. $-736 \mathrm{c}$.

13. Основи існування громадянського суспільства звужуються / Центр О. Разумкова www.uceps.org/expert. php? news_id=1262.

14. Андрущенко В.П. Організоване суспільство. Проблеми організації та суспільної самоорганізації в період радикальних трансформацій в Україні на рубежі століть: Досвід соціально-філософського аналізу / В.П. Андрущенко. - К.: ТОВ "Атлант ЮЕмСі", 2005. - 498 c.

15. Міжнародні організації: навчальний посібник / за ред. О.С. Кучика. - 2-ге вид., перероб. і допов. - К.: Знання, 2007. - 749 с.

16. Резнік О. Особистість і громадянське суспільство: досвід теоретичного осмислення / О. Резнік // Соціологія: теорія, методи, маркетинг. - 2002. - № 3. - С. 68-79.

17. ДСІ, секція неурядових організацій // http://www.un.org/russion/question/ngo-dpi/. 
18. Європейська конвенція про визнання правосуб’єктності міжнародних неурядових організацій http://conventions.coe.int/Treaty/Commun/QueVoulezVous.asp?NT=124\&CM=8\&DF=8/22/2007 $\& C L=E N G$.

19. Пахолок В.М. Місцеве самоврядування у централізованій унітарній державі (на прикладі Франціiі) / В.М. Пахолок // Держава і право: збірник наукових праць. Юридичні і політичні науки / Інститут держави і права ім.Корецького В.М. НАН України. - К., 2010. Вип. 47. - С. 716-721.

\section{ACTIVITIES OF INTERNATIONAL NONGOVERNMENTAL ORGANIZATIONS IN THE LEGISLATIVE AND LEGAL OF UKRAINE}

Summary. The term "international non-governmental organization" (INGO) is formulated as an organized association of public representatives of different countries, created in accordance with national legislation for the achievement of goals and objectives of civil society development and international relations, this organization operates in accordance with universally recognized principles of the UN Charter and international law in the territory of two or more states and has consultative status. It has been found that the types of features which include: goals and tasks, nature of activities, form of organization, availability of consultative status, etc., determine the distinction of an international NGO from other subjects of international relations. Such generic features ( as: the fact of association of people, the existing of permanent governing bodies, statutes, etc.) are common for the whole class (kind) of organizations. It is grounded that INGOs, as a participant of international relations, are subjects of international law, but their legal personality is functional, that is limited to its consultative status. It has been demonstrated that INGOs are an informal link between national governments and the international community, they are actively involved in the development of international standards, methods, models and they relate their national significance to international law. It was noted that the national legislation of Ukraine tends to optimize the development of issues that are related to the legal status of INGOs taking into account international principles and standards. At the same time, it is not possible to copy them in their entirety, because the State, on the basis of its social and historical experience, the experience of the functioning of the legal system, existing social relations and its national interests, is itself entitled to determine the legal status of the INGOs. It is proposed that the amendments to the Law "On Non-Governmental Organizations" would reflect the basic idea that non-governmental organizations are the core of civil society, the most important factor in the development of a democratic state and international relations, a means for citizens to exercise their rights and freedoms.

Keywords: international non-governmental organization, national legislation, law, subject of international relations. 